\title{
Serjania marginata induced inhibition of mycobaterial growth, reduced cytokine and inflammatory parameters
}

Maicon Matos Leitão ( $\sim$ mleitao02@hotmail.com )

UFGD FCS: Universidade Federal da Grande Dourados Faculdade de Ciencias da Saude https://orcid.org/0000-0003-2699-1511

Joyce Alencar Santos Radai

UFGD FCS: Universidade Federal da Grande Dourados Faculdade de Ciencias da Saude

Luis Fernando Benitez Macorini

UFGD FCS: Universidade Federal da Grande Dourados Faculdade de Ciencias da Saude

Thiago Leite Fraga

Centro Universitario da Grande Dourados

\section{Silvia Cristina Heredia Vieira}

Anhanguera University Centre of Campo Grande: Centro Universitario Anhanguera de Campo Grande

Claudia Andrea Lima Cardoso

UEMS: Universidade Estadual do Mato Grosso do Sul

\section{Arielle Cristina Arena}

Department of Morphology, Institute of Biosciences of Botucatu, Paulista State University, Botucatu, SP, BRAZIL

\section{Candida Aparecida Leite Kassuya}

UFGD FCS: Universidade Federal da Grande Dourados Faculdade de Ciencias da Saude

\section{Research Article}

Keywords: Mycobacterium tuberculosis, Bacillus Calmette-Guerin (BCG), cipó-timbó, inflammation, tuberculosis

Posted Date: January 17th, 2022

DOI: https://doi.org/10.21203/rs.3.rs-283967/v2

License: (c) (i) This work is licensed under a Creative Commons Attribution 4.0 International License. Read Full License 


\section{Abstract}

Objectives: This study investigated the antimycobacterial, anti-inflammatory and antihyperalgesic effects of hydroalcoholic extract from leaves of S. marginata (EESM) in in vitro and in vivo models.

Methods and Results: EESM $(0.98-1000 \mu \mathrm{g} / \mathrm{ml})$ was evaluated in in vitro against Mycobacterium tuberculosis, M. bovis, Klebsiella pneumoniae, Pseudomonas aeruginosa, Staphylococcus epidermidis. The EESM oral administration (p.o.) (30, 100 and $300 \mathrm{mg} / \mathrm{kg}$ ) and dexamethasone subcutaneous injection (s.c.) $(1 \mathrm{mg} / \mathrm{kg}$ ) were tested against the carrageenan-induced inflammatory paw edema and pleurisy in Swiss mice. The EESM (30 and $100 \mathrm{mg} / \mathrm{kg}$, p.o.) and dexamethasone (1 mg/kg, s.c.) were tested against the CFA-induced paw inflammation and $M$. bovis (bacillus Calmette-Guerin - BCG)-induced pleurisy in C57bL6 mice. The minimum inhibitory concentration (MIC) of EESM in the presence of $M$. tuberculosis was $62.4 \mu \mathrm{g} / \mathrm{ml}$. The values of MIC of EESM in the presence S. epidermidis, K. pneumoniae were $1000 \mu \mathrm{g} / \mathrm{mL}$ while EESM did not interfere against $P$. aeruginosa growth. EESM significantly inhibited paw edema/mechanical hyperalgesia in carrageenan induced paw inflammation and leukocytes migration/proteins exudation in carrageenan-induced pleurisy model. In the BCG-induced pleurisy model, the daily treatment for 7 days, with EESM inhibited the levels of IL-1 $\beta$ in blood and in pleural exudate. The EESM did not alter the mycobacterial growth in the cell culture from pleural lavage, spleen and liver samples collected from BCG-treated animals. The EESM significantly inhibited the persistent edema and mechanical hyperalgesia induced by CFA.

Conclusion: This study confirms the EESM anti-inflammatory property and showed that EESM has high potency in inducing inhibition of mycobaterial growth and low potency or no effects in relation to other microorganisms.

\section{Introduction}

The immune and inflammatory process respond promptly to the presence of infectious pathogens. If the infectious pathogens persist, the body develops an adaptative immune and inflammatory response ${ }^{[1,2]}$. For the discovery of potential anti-inflammatory/anti-infective agents, the infectious pathogens or PAMPs (Pathogen Associated Molecular Patterns) could be used in experimental models. The inflammatory response to live infectious agents and PAMPs depends on several components, such as leukocytes, receptor pattern recognition receptors (PRR), the complement system, pro-inflammatory mediators, cytokines, among others ${ }^{[2-5]}$. Pharmacological control of an inflammatory response to an aggressive pathogen is carried out using antibiotics. Depending on the development of multi-resistant strategies of pathogen and host response, endogenous and pharmacological control is often not fully effective.

In relation to the prevalence of tuberculosis, a disease caused by Mycobacterium tuberculosis has increased due to the development of resistant strains, the use of anti-tumor necrosis fator (TNF)s and the co-infection by the human immunodeficiency virus ${ }^{[1,6,7]}$. In addition, the currently recommended vaccine, M. bovis - bacillus Calmette-Guerin (BCG), attenuates the development of tuberculosis in severe form in 
children, however it does not prevent primary infection or reactivation of latent tuberculosis infection in adults and new vaccines have been developed ${ }^{[6,7]}$.

The alternative strategies are needed to eliminate the pathogens and also harmful inflammation ${ }^{[4]}$. The plant candidate as alternative source is Serjania marginata Casar. (Sapindaceae) found in Brazil, Paraguay, Bolívia and Argentina ${ }^{[8-10]}$. The traditional knowlegde calls this plant as "cipó-uva" or "cipótimbón ${ }^{[11,12]}$ or blancuzco ${ }^{[10]}$ and the leaves, prepared in the form of juice, are used to treat stomachache by the Guarani Indians ${ }^{[13]}$.

Gastroprotective activity of $S$. marginata leaves aqueous ${ }^{[14]}$ and hydroalcoholic extracts ${ }^{[15]}$ were scientifically shown. ${ }^{[15]}$ also showed that hydroalcoholic extract from leaves of $S$. marginata was antimicrobial, antidiarrheal, and (anti)mutagenic. ${ }^{[16]}$ demonstrated that $S$. marginata leaves aqueous extract was not toxic after a single exposure, however if it was used after prolonged periods it affected some parameters. ${ }^{[15]}$ showed that after 14 days of administration hydroalcoholic extract also affected some parameters such as induce gastric lesions.

The present work was motivated since the description of in vitro antimicrobial property of $S$. marginata was related by ${ }^{[15]}$ and by Serjania $s p$ are used against other infections and inflammatory conditions in folk medicine ${ }^{[13,17,18]}$. This study investigated the anti-inflammatory and anti-mycobacterial activity of hydroalcoholic extract from leaves of $S$. marginata (EESM) in several models contributing to the pharmacological knowledge of this plant.

\section{Material And Methods}

\section{Vegetal material and extract preparation}

Leaves from S. marginata were collected in February 2011 in an area of Cerrado in Dourados, Mato

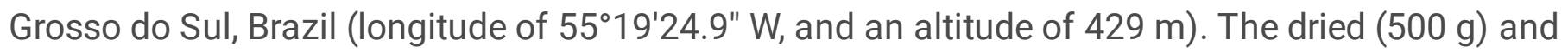
pulverized leaves were extracted by percolation at room temperature with $\mathrm{EtOH} / \mathrm{H}_{2} \mathrm{O}(7: 3, \mathrm{v} / \mathrm{v})$. The hydroalcoholic extract was filtered, concentrated under vacuum $\left( \pm 40^{\circ} \mathrm{C}\right)$, and lyophilized (yield: $33 \%$ $w / w)$. The phytochemical analysis of EESM was performed by ${ }^{[12]}$.

\section{Chemical reagents}

Complete Freund's Adjuvant (CFA), dexamethasone (DEXA), isoniazid, and carrageenan were brought from Sigma-Aldrich (St Louis, MO, USA). Ketamine and xylasine were obtained from Syntec (Santana de Paraíba, SP, Brazil). BCG was obtained from Fundação Ataulpho de Paiva (Rio de Janeiro, Brazil). Dimethylsulfoxide (DMSO) and other reagents were acquired from other suppliers.

\section{In vitro antimycobacterial and antibacterial activity}


The in vitro antimycobacterial activity was performed according to ${ }^{[19]}$. The EESM was dissolved in $5 \%$ of DMSO in a solution of pure water and the minimum inhibitory concentration (MIC) values for EESM was assayed at range of $0.98-250 \mu \mathrm{g} / \mathrm{ml}$ and for isoniazid between $0.004-1 \mu \mathrm{g} / \mathrm{ml}$ in the presence of the M. tuberculosis strain H37Rv (ATCC27294).

The in vitro antibacterial activity methodology was performed according to ${ }^{[20]}$ and ${ }^{[21]}$. The EESM was dissolved in $5 \%$ of tween 80 in a solution of pure water and the minimum inhibitory concentration (MIC) values for EESM was assayed at 8.125, 16.25, 32.5, 75, 125, 250, 500, $1000 \mu \mathrm{g} / \mathrm{ml}$. Bacterial cultures (Klebsiella pneumoniae ATCC 700603, Pseudomonas aeruginosa ATCC 27853, and S. epidermidis ATCC 12228) will be activated through subcultures on Mueller-Hinton agar for $24 \mathrm{~h}$ at $37^{\circ} \mathrm{C}$.

After activation and/or subculture, the bacterial inoculum will be standardized, which consisted of the preparation of a bacterial suspension in sterile saline, standardized on the McFarland 0.5 da scale $(1 \mathrm{x}$ $\left.10^{8} \mathrm{CFU} / \mathrm{ml}\right)$ and diluted 1:10 also in saline $\left(1 \times 10^{7} \mathrm{CFU} / \mathrm{ml}\right)$. After dilution, $10 \mu \mathrm{L}$ volumes will be transferred to the sterile microplate wells, containing a final volume of $100 \mu \mathrm{L}$ of Mueller-Hinton broth plus the different final concentrations of EESM, resulting in a final inoculum of approximately $10 \times 10^{5}$ $\mathrm{CFU} / \mathrm{ml}$ and later taken to greenhouse at $37^{\circ} \mathrm{C}$ for $24 \mathrm{~h}$. The MICs (minimum inhibitory concentrations) in microdilution will be determined by reading in a spectrophotometer at $610 \mathrm{~nm}$ in a microplate observing the lowest concentration in which the EESM will completely inhibit microbial growth ${ }^{[20,21]}$.

\section{Animals, control drugs' administration, EESM dilution and doses for in vivo experiments}

Female and male Swiss $(28-32 \mathrm{~g})$ and C57BL/6 mice $(25-30 \mathrm{~g})$ were provided by the central biotherium at the Federal University of Grande Dourados (UFGD). Animals were kept in polypropylene boxes in a sectorial Biotherium at Faculty of Health Sciences at UFGD with the following conditions: $22^{\circ} \mathrm{C}$, in the presence of a $12 \mathrm{~h}$ light/dark cycle, with food and water ad libitum. The EESM was dissolved in saline solution $(0.9 \%)$ and the dose was calculated according to mice weight. Vehicle solution is the saline solution since it was used to dissolve the EESM. The EESM oral administration (p.o.) doses used in the carrageenan-induced paw inflammation and pleurisy were 30,100 and $300 \mathrm{mg} / \mathrm{kg}$ to verify if the EESM presents a dose-response profile. As the doses of 30 and $100 \mathrm{mg} / \mathrm{kg}$ of EESM were effective against inflammatory parameters, these doses were tested also against BCG-induced pleurisy and CFAinduced inflammatory reaction. To verify the inhibitory efficacy of the commercial drugs, the dose of 1 $\mathrm{mg} / \mathrm{kg}$ (by subcutaneous route - s.c.) of dexamethasone was used as control group in in vivo models while the dose of $25 \mathrm{mg} / \mathrm{kg}$ (p.o.) of isoniazid was used in BCG model.

\section{Paw edema, mechanical and cold hyperalgesia evaluation in carrageenan induced paw inflammation}

The male Swiss mice were distributed in five experimental groups $(n=6)$ and one hour before the carrageenan injection, they were treated (p.o.) with 30,100 and $300 \mathrm{mg} / \mathrm{kg}$ of EESM, with the vehicle and dexamethasone ( $1 \mathrm{mg} / \mathrm{kg}$, s.c.). Subsequently, the animals received a subcutaneous injection $(100 \mu \mathrm{L})$ of a solution containing $300 \mu \mathrm{g}$ of carrageenan ${ }^{[22]}$ dissolved in sterile $0.9 \%$ saline in the right hind paw. The 
contralateral paw, which was used as a control, received $100 \mu \mathrm{L}$ of saline. Paw edema was analyzed using a plethysmometer (Panlab, Spain) at 1, 2 and $4 \mathrm{~h}$ after injection. In addition, mechanical hyperalgesia was assessed using an electronic version of the von Frey test (Analgesimeter von frey, InSight) and cold sensitivity was analyzed with the acetone drop test ${ }^{[23]}$ at 3 and $4 \mathrm{~h}$ after carrageenan injection.

\section{Leukocyte migration and protein analysis in pleural exudate collected from carrageenan induced pleurisy}

Female Swiss mice were distributed in five experimental groups $(n=6)$ and one hour before the pleurisy, they were treated (p.o.) with 30,100 and $300 \mathrm{mg} / \mathrm{kg}$ of EESM, with the vehicle and dexamethasone (1 $\mathrm{mg} / \mathrm{kg}$, s.c.). Subsequently, with the aid of an adapted needle, $100 \mu \mathrm{L}$ of carrageenan (containing $100 \mu \mathrm{g}$ ) was injected into the right side of the animals' chest cavity to induce inflammation [24]. Four hours after the injection of carrageenan, the animals were euthanized $(100 \mathrm{mg} / \mathrm{kg}$ of ketamine and $10 \mathrm{mg} / \mathrm{kg}$ of xylasine by intraperitoneal route (i.p.)) and, afterwards, the exudate was collected by washing the chest cavity with $1 \mathrm{~mL}$ of phosphate buffered saline (PBS). Having made the collection, the total number of leukocytes in the exudate was determined by the KX-21N Sysmex apparatus and the protein exudation was evaluated by the Bradford reaction, using the commercially available Bradford kit (Bioagency, São Paulo, Brazil).

\section{Leukocyte migration, II-1 $\beta$ dosage and CFU growth in BCG-induced pleurisy model}

Groups of six male C57BL/ 6 mice were treated orally with EESM (30 or $100 \mathrm{mg} / \mathrm{kg})$, isoniazid $(25 \mathrm{mg} / \mathrm{kg})$, saline solution ( $0.9 \%$; control group) and saline solution ( $0.9 \%$; naive group). Pleurisy was induced $1 \mathrm{~h}$ after the previous treatment with an intrapleural injection with $0.1 \mathrm{~mL}$ of a suspension of BCG $\left(4 \times 10^{5}\right.$ colony forming units (CFU) into the right pleural cavity. In the naïve group, instead of a BCG injection, the mice received a saline injection in the pleural space. The animals were treated orally with EESM,

isoniazid, saline solution ( $0.9 \%)$ once daily for 7 days ${ }^{[25]}$. After 7 days, the animals were euthanized (100 $\mathrm{mg} / \mathrm{kg}$ of ketamine and $10 \mathrm{mg} / \mathrm{kg}$ of xylasine, i.p.) and the pleural cavity was washed with $1 \mathrm{ml}$ of sterile phosphate buffered saline. The washed sample of $50 \mu \mathrm{L}$ was diluted with Evans blue to determine the total number of leukocytes. The rest of the sample was centrifuged, and the supernatant was stored for the II-1 $\beta$ measurements using ELISA. The blood was also collected from each animal for II-

$1 \beta$ measurements. The precipitate was suspended in $0.5 \mathrm{~mL}$ of sterile ultrapure water and $0.1 \mathrm{~mL}$ of Ogawa Kudu, and $0.1 \mathrm{~mL}$ of the suspension was plated onto $7 \mathrm{H} 11$ agar. The spleen and liver were macerated with $1 \mathrm{~mL}$ of sterile saline solution, and $0.1 \mathrm{~mL}$ of the suspension was plated on $7 \mathrm{H} 11$ agar. The cells were cultured for 60 days at $37^{\circ} \mathrm{C}$ in $5 \% \mathrm{CO}_{2}{ }^{[26]}$.

\section{Paw edema, mechanical and cold hyperalgesia evaluation in CFA induced paw inflammation for 22 days}

Groups of six male C57BL/ 6 mice were treated with vehicle (control group), EESM (30 and $100 \mathrm{mg} / \mathrm{kg}$, p.o.), and dexamethasone $1 \mathrm{mg} / \mathrm{kg}$ (s.c., the positive control group) every day, once a day for 22 days. After the first treatment, the animals received $30 \mu \mathrm{L}$ of Freund's complete adjuvant (CFA) (oil suspension 
containing inactive M.tuberculosis) via intraplantar injection in the right paw. Mechanical and cold sensitivity and paw edema were measured $6,11,16$ and 22 days after the injection of CFA.

\section{Statistical analysis}

The data are presented as the mean \pm standard error (SEM). The determination of significant differences among groups was made via one-way analysis of variance (ANOVA) and the Newman-Keuls test was chosen as a post hoc (GraphPad Prism Software). The percentage of inhibition was calculated from the control group. Differences were considered to be significant when $p<0.05$.

\section{Results}

\section{Effects of EESM on M. tuberculosis and other microorganisms in vitro}

The MIC value of EESM in the presence of the M. tuberculosis strain was $62.4 \mu \mathrm{g} / \mathrm{ml}$, while the MIC value of isoniazid was $0.030 \mu \mathrm{g} / \mathrm{ml}$. EESM was effective against $S$. epidermidis, K. pneumoniae in $1000 \mu \mathrm{g} / \mathrm{ml}$ and was not effective against $P$. aeruginosa.

\section{Effects of EESM on paw edema induced by carrageenan}

The paw edema was significantly inhibited at doses of 100 and $300 \mathrm{mg} / \mathrm{kg}$ of EESM after $2 \mathrm{~h}$ of carrageenan injection with inhibition of $38 \%$ and $44 \%$, respectively $(p<0.05)$ (Figures 1B). After $4 \mathrm{~h}$, all doses showed significant differences from the control group with inhibition of $36 \%, 33 \%$ and $58 \%$ in doses $30,100(p<0.05)$ and $300 \mathrm{mg} / \mathrm{kg}(p<0.01)$. The dexamethasone group showed significant inhibition at 1,2 and $4 \mathrm{~h}$.

Dexamethasone was different from all treated groups when the comparison among groups was perfomed (Figures 1A-C). The groups treated with doses of 100 and $300 \mathrm{mg} / \mathrm{kg}$ differed from the control and from the group treated with $30 \mathrm{mg} / \mathrm{kg}$ of EESM (Figure 1B) and in figure $1 \mathrm{C}$ the groups treated with doses of 30 and $100 \mathrm{mg} / \mathrm{kg}$ differed from the control and from group treated with $300 \mathrm{mg} / \mathrm{kg}$ of EESM.

In the carrageenan induced mechanical hyperalgesia, $100 \%$ inhibition was observed in two evaluations at the dose of $300 \mathrm{mg} / \mathrm{kg}$ and the dexamethasone group $(p<0.001)$ (Figures $2 \mathrm{~A}$ and $2 \mathrm{~B}$ ). The dose of $100 \mathrm{mg} / \mathrm{kg}$ also demonstrated prevention of hyperalgesia development, with $100 \%(p<0.001)$ and $96 \%$ $(p<0.01)$ efficacy, in 3 and $4 \mathrm{~h}$ after carrageenan injection, respectively (Figures $2 \mathrm{~A}$ and 2B). The dose of $30 \mathrm{mg} / \mathrm{kg}$ was not effective for the prevention of carrageenan paw hyperalgesia. The control and the group treated with $30 \mathrm{mg} / \mathrm{kg}$ of EESM differed significantly from the other treated groups (Figures 2A and $2 B$ ). The groups treated with doses of $100,300 \mathrm{mg} / \mathrm{kg}$ and dexamethasone did not differ among themselves (Figure 2A) and in figure 2B the groups treated with doses of $300 \mathrm{mg} / \mathrm{kg}$ and dexamethasone differed from the other treated groups.

In the cold nociceptive response, no doses showed a significant difference from control group, however the dexamethasone group obtained an inhibition of $52 \%$ and $49 \%(p<0.05)$ in 3 and 4 h, respectively 
(Figures 2C and 2D).

\section{Effects of EESM on pleurisy induced by carrageenan}

In pleurisy induced by carrageenan, EESM 100 and $300 \mathrm{mg} / \mathrm{kg}$ significantly reduced leukocyte migration $(p<0.001)$ by 59 and $67 \%$, respectively, compared to the control group (Figure $3 \mathrm{~A})$. In protein exudation evaluation, EESM demonstrated significant difference $(p<0.001)$, with 53,42 and $60 \%$ of inhibition, at doses 30,100 and $300 \mathrm{mg} / \mathrm{kg}$, respectively. The dexamethasone group also demonstrated a significant decrease in both evaluations $(p<0.001)$ (Figure 3 ).

The statistical comparison among groups showed that control and the group treated with $30 \mathrm{mg} / \mathrm{kg}$ of EESM differed from the other groups in Figure 3A while only control group differed from others groups in Figure 3B.

\section{Effects of EESM on Leukocyte migration, II-1 $\beta$ dosage and CFU growth in BCG-induced pleurisy model}

After 7 days of oral treatment, EESM ( 30 and $100 \mathrm{mg} / \mathrm{kg}$ ) did not decrease the leukocyte migration into the pleural spaces after intrathoracic injection of BCG, however isoniazid reduced significantly the leukocyte invasion to the pleura (Figure 4A). In pleural exudates, the reduction of IL-1 $\beta$ levels were significant with inhibition of $72 \%$ and $76 \%$ with the treatment of 30 and $100 \mathrm{mg} / \mathrm{kg} \mathrm{EESM} \mathrm{(p.o.)} \mathrm{and} 76$ $\%$ isoniazid ( $25 \mathrm{mg} / \mathrm{kg}$, p.o.) (Figure 4B). In serum, the reduction of IL-1 $\beta$ levels were significant with inhibition $50 \%$ and $59 \%$ with the treatment of 30 and $100 \mathrm{mg} / \mathrm{kg}$ EESM (p.o.) and $67 \%$ isoniazid (25 $\mathrm{mg} / \mathrm{kg}$, p.o.) (Figure $4 \mathrm{C}$ ). The statistical comparison among groups showed that only the control group differed from the other groups in Figures $4 \mathrm{~B}$ and $4 \mathrm{C}$.

During the cell culture of the pleural lavage, spleen and liver samples collected from BCG treated animals, the EESM (30 or $100 \mathrm{mg} / \mathrm{kg}$ ) did not alter the mycobacteria growth (results not shown) and the UFC count did not differ from control group (results not shown) until 60 days. The negative control group samples presented mycobacterial growth in all cultivated plaques, with a mean of 54 CFU after 60 days of culture, while the isoniazid group samples did not show any growth after 60 days (results not shown).

\section{Effects of EESM on CFA induced paw inflammation}

A single daily oral treatment with EESM for 6 days at doses of 30 and $100 \mathrm{mg} / \mathrm{kg}$ and dexamethasone (1 $\mathrm{mg} / \mathrm{kg}$, s.c.) reduced mechanical hyperalgesia in $100 \%$ respectively (Figure 5A). After 11 and 16 days from CFA injection, no significant inhibitions in mechanical response were observed with $30 \mathrm{mg} / \mathrm{kg}$ of EESM, however a significant inhibition was detected with dexamethasone (Figure 5B and 5C). At 22 days after CFA, the inhibition observed with $30 \mathrm{mg} / \mathrm{kg}$ of EESM was $100 \%$ (Figure 5D). The groups treated with EESM (30 and $100 \mathrm{mg} / \mathrm{kg}$ ) did not differ statistically among themselves at days 6, 11 and 16, however they were different from the dexamethasone group on 11 and 16 days (Figures $5 \mathrm{~A}-\mathrm{C}$ ). The group treated with $100 \mathrm{mg} / \mathrm{kg}$ differed from the group treated with $30 \mathrm{mg} / \mathrm{kg}$ at 22 days after CFA injection (Figure 5D). 
The dose of $100 \mathrm{mg} / \mathrm{kg}$, but not the dose of $30 \mathrm{mg} / \mathrm{kg}$ of EESM and dexamethasone groups showed a significant difference in paw edema on days 6 and 11 after the administration of CFA with the inhibition of $21 \%$ and $47 \%$, respectively (Figures $6 \mathrm{~A}$ and $6 \mathrm{~B}$ ). On days 16 and 22 , the doses of $30,100 \mathrm{mg} / \mathrm{kg}$ of EESM and dexamethasone groups were different from the control groups with inhibitions of $33 \%, 50 \%$ and $65 \%$ on day 16 and $57 \%, 67 \%$ and $87 \%$ on day 22 , and $57 \%, 67 \%$ and $87 \%$ on day 22 , respectively (Figures $6 \mathrm{C}$ and 6D). The treatment with $100 \mathrm{mg} / \mathrm{kg}$ did not statistically differ from dexamethasone group on days 6, 11 and 16, however on day 22 these groups were statistically different (Figure 6). Both treatments with EESM were not statistically different to dexamethasone group on day 16 , nevertheless on day 22 both treatments with EESM differed from dexamethasone group.

In cold hyperalgesia induced by CFA, the treatment with EESM at dose of $100 \mathrm{mg} / \mathrm{kg}$ was statistically different from the control group, with the inhibition 52 \% showing similarity inhibition to dexamethasone group on day 6 . The treatments with both doses of EESM did not differ from the control group on days 11,16 and 22.

\section{Discussion}

Species of the Serjania genus have been used in folk medicine for their anti-inflammatory potential in Brazil and in Mexico ${ }^{[27]}$ while $S$. marginata leaves are squeezed for juice by the Bolivian people as an analgesic agent for stomach ${ }^{[13]}$. The present study was the first one to show the anti-inflammatory, analgesic and potential antibiotic properties of EESM in inflammatory/infection/hyperalgesic models. The data of the present work corroborate with the traditional folk use of $S$. marginata as an analgesic and expand the information regarding its use.

Some inflammatory models used in this present research involve carrageenan and CFA. The carrageenan was used in two acute inflammatory models to analyze the efficacy and potency of anti-inflammatory agents until $48 \mathrm{~h}^{[28]}$. When the carrageenan is administered into the mice paw the edema, mechanical and cold hyperalgesia can be measured ${ }^{[29]}$ and when it is injected by intrapleural route the leukocyte and protein can be measured in pleural exudate ${ }^{[30]}$. In the present study the EESM showed to be effective against acute edema (2, and $4 \mathrm{~h}$, Figure $1 \mathrm{~B}$ and $1 \mathrm{C})$, mechanical hyperalgesia ( 3 and $4 \mathrm{~h}$, Figures $2 \mathrm{~A}$ and $2 \mathrm{~B}$ ), however the cold hyperalgesia (Figures $2 \mathrm{C}$ and 2D) was not inhibited in carrageenan paw inflammatory model. In the carrageenan induced-pleurisy model, both leukocyte migration and protein exudation were inhibited by EESM (Figures $3 \mathrm{~A}$ and $3 \mathrm{~B}$ ). In this model, the EESM induced a dose dependent inhibition (Figures 1B, 1C, 2A, 2B and $3 A$ ) in which the efficacy response to EESM differed significantly when its dose was increased. In Figure 2B the classical dose-response effect could be detected since each dose of EESM significantly differed in efficacy among themselves. As far as we know, only the research of ${ }^{[15]}$ showed the myeloperoxidase activity inhibition by EESM in ulcer models. The present study showed the anti-inflammatory and mechanical anti-hyperalgesic (analgesic) response of EESM occurs a dose-dependent manner. 
The major compounds such as flavonoids, proanthocyanidins and saponins have already been described in EESM ${ }^{[12]}$. Flavonoids and proanthocyanidins (tannins) are the chemical classes related to the antioxidant and anti-inflammatory activities of some plant species. Flavonoids, due to their chemical structure and their redox capacity, can interfere in important mechanisms that are related to inflammatory processes such as enzyme inhibition ${ }^{[31,32]}$. Proanthocyanidins have anti-inflammatory potential that could modulate the arachidonic acid and the nuclear factor NF-kB [33]. [12,15] showed that EESM gastroprotective property is associated with the presence of proanthocyanidins and flavonoids. Other substances present in EESM are pulsatilla $D$, hederacolchiside $A 1$, salzmannianosid $B$ and serjanioside $D$ (saponins), epicatechin, cassiaoccidentalin A, tetrastigma B and serjanone A (flavonoids), proanthocyanidins $\mathrm{A}-1$ and $\mathrm{A}-2$ and cinnamtannin $\mathrm{B}-{ }^{\left[{ }^{[12}\right]}$. The flavonoids, proanthocyanidins and saponins could be responsible for the EESM anti-inflammatory activity.

The EESM was also tested in vitro against gram-negative and gram-positive bacteria. The MIC of EESM in the presence of the $M$. tuberculosis was $62.4 \mu \mathrm{g} / \mathrm{ml}$ showing to be a promising antibacterial natural agent. ${ }^{[34]}$ indicated that an ethanolic extract of $S$. erecta, another species of Serjania genus, demonstrated a MIC of $128.0 \mu \mathrm{g} / \mathrm{ml}$ and EESM showed to be twice more potent than this extract. The values of MIC of EESM in the presence $S$. epidermidis and K. pneumoniae was $1000 \mu \mathrm{g} / \mathrm{ml}$ indicating that EESM had low potency in inducing inhibition of other bacteria growth. ${ }^{[15]}$ showed that the hydroethanolic extract from $S$. marginata had in vitro antibacterial and antifungal activities of the HESM against $S$. aureus (MIC of $125 \mathrm{mg} / \mathrm{mL}$ ), E. coli (MIC of $250 \mathrm{mg} / \mathrm{mL}$ ), S. setubal (MIC of $250 \mathrm{mg} / \mathrm{mL}$ ), and C. albicans (MIC of $250 \mathrm{mg} / \mathrm{mL}$ ). EESM was not effective against $P$. aeruginosa growth. These set of results showed that EESM has high potency in inducing inhibition of mycobaterial growth and low potency or no effects in relation to other microorganisms.

Since the EESM activity seems to be more selective against $M$. tuberculosis than to other microorganisms the in vivo EESM potential against mycobacteria was performed. The EESM was tested in BCG-induced pleurisy since it is not possible to work with M. tuberculosis in vivo in our University. Another reason to work with BCG as a mycobacteria model, is that its immunization schedule is applied against tuberculosis at birth in various countries. The licensed vaccine with attenuated BCG is performed in health care and several new vaccines are in clinical phases ${ }^{[6]}$. BCG was inoculated in the interpleural space, inducing an infectious and inflammatory mycobacterial response confirmed by the results of the control groups compared to the naive group (Figure 4). The results of leukocyte migration into the pleural space, IL-1 $\beta$ levels in serum and in pleural exudate in the negative control group significantly differed from those of the naïve group after 7 days. In BCG pleurisy model, oral doses of 30 and $100 \mathrm{mg} / \mathrm{kg}$ of EESM did not interfere with leukocyte migration to the pleural exudate however it induced a significant inhibition on the interleukin-1 beta (IL-1 $\boldsymbol{\beta}$ ) levels in serum and pleural exudate. The increase in IL-1 $\beta$ levels after 7 days in BCG model may be correlated with the mycobacterial growth, as showed previously by our group ${ }^{[26]}$. ${ }^{[35]}$ indicated that mice deficient in interleukin (IL) showed reduction in bacterial load $\mathbf{3 5}$ days' post infection. Tumor necrosis factor alpha (TNF-a) and IL-1 $\beta$ are produced by immune cells that are 
involved in pulmonary tuberculosis ${ }^{[36,37]}$. These results showed that doses of EESM controlled the BCGinflammation.

An aliquot of precipitate sample from pleural exudate and also spleen and liver macerate from all BCGinjected animals were platted in Middlebrook 7H9/Ogawa Kudu culture medium for analysis of BCG growth. The BCG culture was found positive for Ziehl-Neelsen stain confirming that this microorganism is a Mycobacterium sp. The isoniazid inhibited significantly all the aspects of in vivo inflammatory response (Figure 4) including mycobacterial growth in vitro and in vivo. The EESM was not able to inhibit the formation of CFUs in pleural exudate, liver, and spleen tissues from in vivo experiments. The absence of EESM antibacterial effects may be related to the route of administration, dose and pharmacokinetics/pharmacodynamics of the EESM. To verify if EESM inhibited the BCG in vitro, the attenuated BCG was reactived in Lowenstein Jensen medium (an inclined tube under standard growth

conditions) ${ }^{[38]}$ and subsequently EESM was added to evaluation of antimicrobial activity in vitro. Several concentrations until $4 \mathrm{mg} / \mathrm{ml}$ of EESM were tested against BCG in vitro therefore no inhibitions were detected demonstrating no EESM antibacterial and/or bacteriostatic effects.

The EESM was also tested against CFA (an oil suspension containing killed M. tuberculosis), an immunogenic/inflammatory stimulus since it is not possible to work with viable $M$. tuberculosis ${ }^{[39]}$. The CFA induced persistent edema, mechanical hyperalgesia and cold sensitivity in control animals for 22 days. We observed the inhibition of the formation of paw edema with similar results to the dexamethasone group for 22 days, with a significant difference in the dose of $100 \mathrm{mg} / \mathrm{kg}$ of EESM in all evaluations and on days 16 and 22 in the dose of $30 \mathrm{mg} / \mathrm{kg}$, comparing to the group control (Figures 6AD). In the assessment of mechanical hyperalgesia, the EESM showed a significant difference compared to the control group on day 22 (Figure 5D). These results demonstrated that chronic anti-inflammatory ability of EESM even also in the persistent CFA model of inflammation.

\section{Conclusion}

The present study was the first one to show the anti-inflammatory, anti-hyperalgesic and potential antibiotic properties of EESM in inflammatory/infection/hyperalgesic in acute and persistent models. EESM has high potency in inducing inhibition of mycobaterial growth and low potency or no effects in relation to other microorganisms in in vitro. EESM chemical composition showed the presence of several classes of compounds such as flavonoids, proanthocyanidins and saponins could be responsible for the EESM anti-inflammatory activity.

\section{Declarations}

\section{Financial Support and Sponsorship}

Nil. 
The author(s) confirm that this article content has no conflicts of interest.

\section{Acknowledgments}

The authors would like to thank School of Health Sciences, Federal University of Grande Dourados, Dourados, Mato Grosso do Sul State, Brazil, National Council for Scientific and Technological Development (CNPq), Support Foundation for the Development of Education, Science and Technology of the State of Mato Grosso do Sul (FUNDECT), and Coordination for the Improvement of Higher Education Personnel (CAPES), Fund for Support to Teaching, Research and Outreach Activities of University of Campinas (FAEPEX-UNICAMP).

\section{Ethics approval}

The register code for research A9CDAAE was obtained from National System for the Management of Genetic Heritage and Associated Traditional Knowledge (SISGEN). A specimen was deposited at the Herbarium of the Federal University of the Mato Grosso do Sul, Brazil under the number 41054. Approval of the animal protocols were granted by the UFGD ethics committee (33/2016) and of University center of Grande Dourados (UNIGRAN) ethics committee (No. 050/2020).

\section{Authors' contributions}

All authors participated in the design, interpretation of the studies, analysis of the data and review of the manuscript; Maicon Matos Leitão and Silvia Cristina Heredia Vieira conducted the anti-inflammatory and analgesic evaluation; Luis Fernando Benitez Macorini, Thiago Leite Fraga and Joyce Alencar Santos Radai conducted the antimicrobial and antimycobacterial evaluation; Claudia Andrea Lima Cardoso and Silvia Cristina Heredia Vieira were involved in the preparation of extract; Candida Aparecida Leite Kassuya, Arielle Cristina Arena and Maicon Matos Leitão performed data analyses and wrote the manuscript. All authors read and approved the manuscript and all data were generated in-house and that no paper mill was used.

\section{Abbreviations}

Complete Freund's Adjuvant (CFA), Dimethylsulfoxide (DMSO), Interleukin-1 $\beta$ (IL-1 $\beta$ ), Mycobacterium bovis - Bacillus Calmette-Guerin (BCG), Receptor pattern recognition receptors (PRR), Tumor necrosis fator (TNF).

\section{Summary}

This study investigated the antimycobacterial, anti-inflammatory and antihyperalgesic effects of $S$. marginata (EESM) in in vitro and in vivo models. The minimum inhibitory concentration in the presence of $M$. tuberculosis was $62.4 \mu \mathrm{g} / \mathrm{ml}$, S. epidermidis and K. pneumoniae were $1000 \mu \mathrm{g} / \mathrm{mL}$ while did not interfere against $P$. aeruginosa growth. EESM significantly inhibited paw edema, mechanical 
hyperalgesia, leukocytes migration and proteins extravasation. Inhibited the levels of IL-1 $\beta$ in blood and in pleural exudate, did not altering the mycobacterial growth in the cell culture from pleural lavage, spleen and liver. This study confirms the EESM anti-inflammatory property and showed that EESM has high potency in inducing inhibition of mycobaterial growth.

\section{References}

1. Doddam SN, Peddireddy V, Yerra P, Sai Arun PP, Qaria MA, Baddam R, et al. Mycobacterium tuberculosis DosR regulon gene Rv2004c contributes to streptomycin resistance and intracellular survival. Int J Med Microbiol 2019;309(8):151353.

2. Frizinsky S, Haj-Yahia S, Machnes Maayan D, Lifshitz Y, Maoz-Segal R, Offengenden I, et al. The innate immune perspective of autoimmune and autoinflammatory conditions. Rheumatology (Oxford) 2019;58(Supplement_6):vi1-8.

3. Kumar D, Romero Y, Schuck KN, Smalley H, Subedi B, Fleming SD. Drivers and regulators of humoral innate immune responses to infection and cancer. Mol Immunol 2020;121:99-110.

4. Mookherjee N, Anderson MA, Haagsman HP, Davidson DJ. Antimicrobial host defence peptides: functions and clinical potential. Nat Rev Drug Discov 2020;19(5):311-32.

5. Sonnenberg GF, Hepworth MR. Functional interactions between innate lymphoid cells and adaptive immunity. Nat Rev Immunol 2019;19(10):599-613.

6. Pérez I, Uranga S, Sayes F, Frigui W, Samper S, Arbues A, et al. Live attenuated TB vaccines representing the three modern Mycobacterium tuberculosis lineages reveal that the Euro-American genetic background confers optimal vaccine potential. EBioMedicine 2020;55:102761.

7. Ryndak MB, Laal S. Mycobacterium tuberculosis Primary Infection and Dissemination: A Critical Role for Alveolar Epithelial Cells. Front Cell Infect Microbiol 2019;9:299.

8. Acevedo-Rodriguez P. Distributional patterns in Brazilian Serjania (Sapindaceae). Acta Bot Bras 1990;4:69-82.

9. Lista do Brasil - Serjania marginata Casar. [Internet]. [citado 2021 out 16];Available from: http://floradobrasil.jbrj.gov.br/jabot/FichaPublicaTaxonUC/FichaPublicaTaxonUC.do?id=FB20963

10. Ferrucci, M.S. Sapindaceae. In: Spichiger, R. \& Ramella, L. Flora del Paraguay. St. Louis: Missouri Botanical Garden; 1991.

11. Corrêa, M. P., Pena, L. A. Dicionário das plantas úteis do Brasil e das exóticas cultivadas. Rio de Janeiro: Ministério da Agricultura, Instituto Brasileiro de Desenvolvimento Florestal; 1984. 
12. Heredia-Vieira SC, Simonet AM, Vilegas W, Macías FA. Unusual C,O-Fused Glycosylapigenins from Serjania marginata Leaves. J Nat Prod 2015;78(1):77-84.

13. Bourdy G, Chāvez de Michel LR, Roca-Coulthard A. Pharmacopoeia in a shamanistic society: the Izoceño-Guaraní (Bolivian Chaco). J Ethnopharmacol 2004;91(2-3):189-208.

14. do Carmo Ota E, Honorato CA, Heredia-Vieira SC, Flores-Quintana Cl, de Castro Silva TS, Inoue LAKA, et al. Hepatic and gastroprotective activity of Serjania marginata leaf aqueous extract in Nile tilapia (Oreochromis niloticus). Fish Physiol Biochem 2019;45(3):1051-65.

15. Périco LL, Heredia-Vieira SC, Beserra FP, de Cássia Dos Santos R, Weiss MB, Resende FA, et al. Does the gastroprotective action of a medicinal plant ensure healing effects? An integrative study of the biological effects of Serjania marginata Casar. (Sapindaceae) in rats. J Ethnopharmacol 2015;172:31224.

16. da Silva Moreira S, Tamashiro LK, Jorge BC, da Silva Balin P, Heredia-Vieira SC, de Almeida GL, et al. Toxicological safety evaluation in acute and 28-day studies of aqueous extract from Serjania marginata Casar. (Sapindaceae) leaves in rats. Journal of Ethnopharmacology 2019;231:197-204.

17. Castelo APC, Arruda BN, Coelho RG, Honda NK, Ferrazoli C, Pott A, et al. Gastroprotective effect of Serjania erecta Radlk (Sapindaceae): involvement of sensory neurons, endogenous nonprotein sulfhydryls, and nitric oxide. J Med Food 2009;12(6):1411-5.

18. de Lima MRF, de Souza Luna J, dos Santos AF, de Andrade MCC, Sant'Ana AEG, Genet J-P, et al. Anti-bacterial activity of some Brazilian medicinal plants. J Ethnopharmacol 2006;105(1-2):137-47.

19. Palomino J-C, Martin A, Camacho M, Guerra H, Swings J, Portaels F. Resazurin microtiter assay plate: simple and inexpensive method for detection of drug resistance in Mycobacterium tuberculosis. Antimicrob Agents Chemother 2002;46(8):2720-2.

20. National Committee for Clinical Laboratory Standards (NCCLS). Performance standards for antimicrobial susceptibility testing. 2002;

21. Campos JF, dos Santos UP, Macorini LFB, de Melo AMMF, Balestieri JBP, Paredes-Gamero EJ, et al. Antimicrobial, antioxidant and cytotoxic activities of propolis from Melipona orbignyi (Hymenoptera, Apidae). Food and Chemical Toxicology 2014;65:374-80.

22. Winter CA, Risley EA, Nuss GW. Carrageenin-induced edema in hind paw of the rat as an assay for antiiflammatory drugs. Proc Soc Exp Biol Med 1962;111:544-7.

23. Decosterd I, Woolf CJ. Spared nerve injury: an animal model of persistent peripheral neuropathic pain. Pain 2000;87(2):149-58. 
24. Vinegar R, Truax JF, Selph JL. Some quantitative temporal characteristics of carrageenin-induced pleurisy in the rat. Proc Soc Exp Biol Med 1973;143(3):711-4.

25. Andrade-Silva M, Correa LB, Candéa ALP, Cavalher-Machado SC, Barbosa HS, Rosas EC, et al. The cannabinoid 2 receptor agonist $\beta$-caryophyllene modulates the inflammatory reaction induced by Mycobacterium bovis BCG by inhibiting neutrophil migration. Inflamm Res 2016;65(11):869-79.

26. Kassuya R, Radai J, Macorini L, Nunes V, Salvador M, Leite P, et al. Blutaparon portulacoides ethanolic extract reduced IL-1 $\beta$ and inflammatory parameters induced by the Mycobacterium complex and carrageenan in mice. Inflammopharmacology 2021;29.

27. Salinas-Sánchez DO, Jiménez-Ferrer E, Sánchez-Sánchez V, Zamilpa A, González-Cortazar M, Tortoriello J, et al. Anti-Inflammatory Activity of a Polymeric Proanthocyanidin from Serjania schiedeana. Molecules 2017;22(6):E863.

28. Posadas I, Bucci M, Roviezzo F, Rossi A, Parente L, Sautebin L, et al. Carrageenan-induced mouse paw oedema is biphasic, age-weight dependent and displays differential nitric oxide cyclooxygenase-2 expression. British Journal of Pharmacology 2004;142(2):331-8.

29. Dos Santos E, Leitão MM, Aguero Ito CN, Silva-Filho SE, Arena AC, Silva-Comar FM de S, et al. Analgesic and anti-inflammatory articular effects of essential oil and camphor isolated from Ocimum kilimandscharicum Gürke leaves. J Ethnopharmacol 2021;269:113697.

30. Leitão MM, Radai JAS, Ferrari IC, Negrão FJ, Silva-Filho SE, Oliveira RJ, et al. Effects of an ethanolic extract and fractions from Piper glabratum (Piperaceae) leaves on pain and inflammation. Regulatory Toxicology and Pharmacology 2020;117:104762.

31. Hernández-Rodríguez P, Baquero LP, Larrota HR. Chapter 14 - Flavonoids: Potential Therapeutic Agents by Their Antioxidant Capacity [Internet]. In: Campos MRS, organizador. Bioactive Compounds. Woodhead Publishing; 2019 [citado 2021 ago 27]. página 265-88.Available from: https://www.sciencedirect.com/science/article/pii/B9780128147740000141

32. Maleki SJ, Crespo JF, Cabanillas B. Anti-inflammatory effects of flavonoids. Food Chem 2019;299:125124.

33. Cádiz-Gurrea MDLL, Borrás-Linares I, Lozano-Sánchez J, Joven J, Fernández-Arroyo S, SeguraCarretero A. Cocoa and Grape Seed Byproducts as a Source of Antioxidant and Anti-Inflammatory Proanthocyanidins. Int J Mol Sci 2017;18(2):E376.

34. Cardoso CAL, Coelho RG, Honda NK, Pott A, Pavan FR, Leite CQF. Phenolic compounds and antioxidant, antimicrobial and antimycobacterial activities of Serjania erecta Radlk. (Sapindaceae). Braz J Pharm Sci 2013;49:775-82. 
35. Bourigault M-L, Segueni N, Rose S, Court N, Vacher R, Vasseur V, et al. Relative contribution of IL$1 \mathrm{a}, \mathrm{IL}-1 \beta$ and TNF to the host response to Mycobacterium tuberculosis and attenuated M. bovis BCG. Immun Inflamm Dis 2013;1(1):47-62.

36. Jayaraman P, Sada-Ovalle I, Nishimura T, Anderson AC, Kuchroo VK, Remold HG, et al. IL-1 $\beta$ Promotes Antimicrobial Immunity in Macrophages by Regulating TNFR Signaling and Caspase-3 Activation. The Journal of Immunology 2013;190(8):4196-204.

37. Weiss DI, Ma F, Merleev AA, Maverakis E, Gilliet M, Balin SJ, et al. IL-1 $1 \beta$ Induces the Rapid Secretion of the Antimicrobial Protein IL-26 from Th17 Cells. The Journal of Immunology 2019;203(4):911-21.

38. Njeru SN, Muema JM. Antimicrobial activity, phytochemical characterization and gas chromatography-mass spectrometry analysis of Aspilia pluriseta Schweinf. extracts. Heliyon 2020;6(10):e05195.

39. Dubé J-Y, McIntosh F, Zarruk JG, David S, Nigou J, Behr MA. Synthetic mycobacterial molecular patterns partially complete Freund's adjuvant. Sci Rep 2020;10(1):5874.

\section{Figures}

A

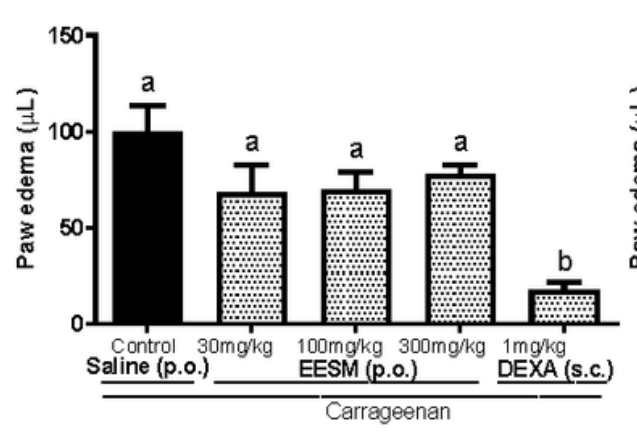

B

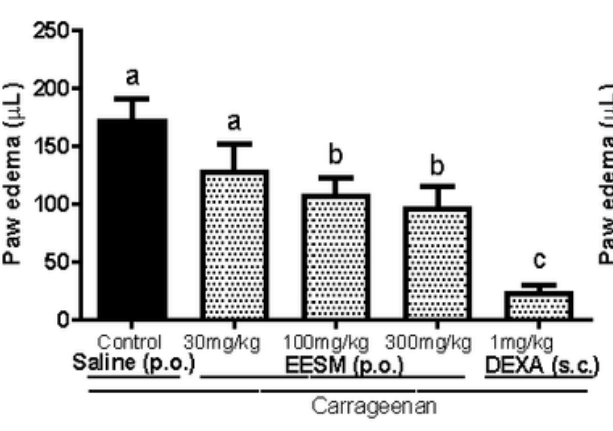

C

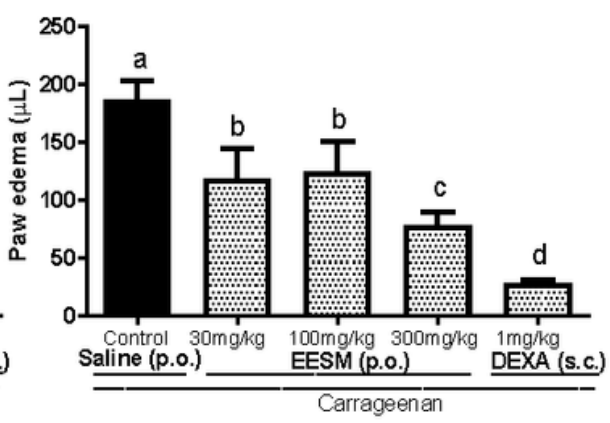

Figure 1

Effect of EESM oral treatments at 1 (A), 2 (B) and 4 (C) hour after carrageenan-induced edema. The control (saline $0.9 \%$, p.o.), EESM (30, 100, or $300 \mathrm{mg} / \mathrm{kg}$, p.o.), and DEXA (dexamethasone $1 \mathrm{mg} / \mathrm{kg}$, i.p.) groups were treated $1 \mathrm{~h}$ before the carrageenan injection. Each bar represents the mean \pm SEM. The letters $a, b, c$, and d indicate significant differences among groups according to One-way ANOVA followed by the Newman-Keuls test

Figure 2 
Effect of EESM oral treatment at 3 and $4 \mathrm{~h}$ after carrageenan-induced mechanical sensitivity (Figures $2 \mathrm{~A}$ and $2 \mathrm{~B}$ ) and cold hypersensitivity (Figures $2 \mathrm{C}$ and $2 \mathrm{D}$ ). The control (saline $0.9 \%$, p.o.), EESM (30, 100, or $300 \mathrm{mg} / \mathrm{kg}$, p.o.), and DEXA (dexamethasone $1 \mathrm{mg} / \mathrm{kg}$, s.c.) groups were treated before $1 \mathrm{~h}$ of carrageenan injection in the paw. Each bar represents the mean \pm SEM. The letters $a, b$ and $c$ indicate significant differences among groups according to One-way ANOVA followed by the Newman-Keuls test

\section{Figure 3}

Effect of EESM oral administration on (A) leukocyte migration $\times 10^{6}$ cells/cavity, (B) proteins $(\mathrm{mg} / \mathrm{ml})$ induced by intrapleural injection of carrageenan in mice. The control group received saline solution ( 0.9 $\%$ ), and the EESM groups received 30,100 , or $300 \mathrm{mg} / \mathrm{kg}$ of EESM. Each bar represents the mean \pm SEM. The letters $a$ and $b$ indicate significant differences among groups according to One-way ANOVA followed by the Newman-Keuls test 

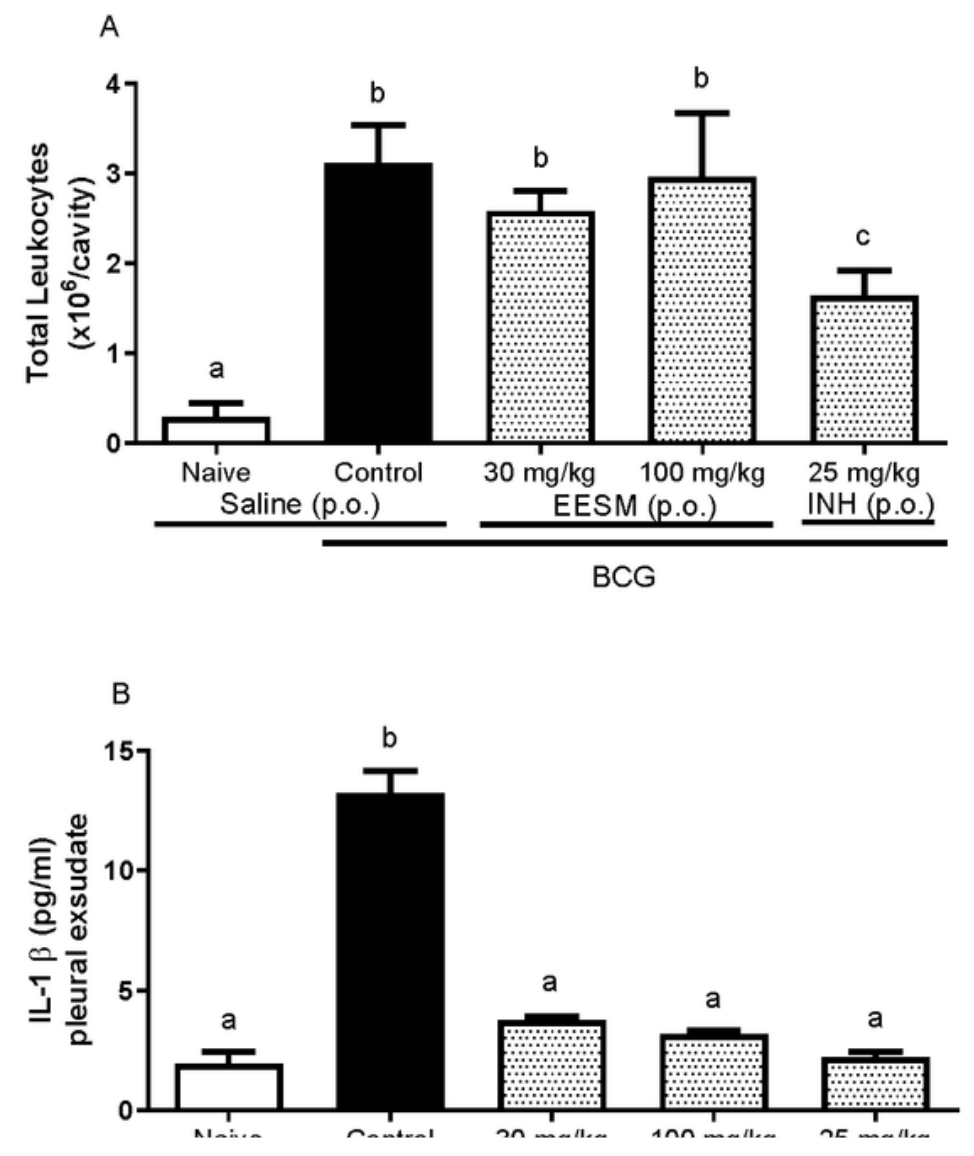

\section{Figure 4}

Effects of EESM oral treatment on leukocyte (A) in the pleurisy, II-1ه levels pleural exudate (B), and in blood (C) induced by BCG. The animals received EESM (30, or 100, p.o.), vehicle (control) or isoniazid (ISO, $25 \mathrm{mg} / \mathrm{kg}$, p.o.) for 7 days and an intrathoracic injection of BCG was administered since the first day. The naive group received an intrapleural injection of sterile saline instead of BCG and was also treated with saline solution. Each bar represents the mean \pm SEM of 6 animals. The letters $a, b$, and $c$ 
indicate significant differences among groups according to One-way ANOVA followed by the NewmanKeuls test

\section{Figure 5}

Effects of oral administration of EESM on mechanical hyperalgesia induced by CFA. The animals received $\operatorname{EESM~(30,~or~100,~p.o.,~daily,~once~a~day),~vehicle~(control)~or~dexamethasone~(DEXA,~} 1 \mathrm{mg} / \mathrm{kg}$, s.c., daily, once a day) for 6 (A), 11(B), 16 (C), and 22 (D) days. The CFA injection was performed on the first day. Each bar represents the mean \pm SEM of 6 animals. The letters $a, b$, and $c$ indicate significant differences among groups according to One-way ANOVA followed by the Newman-Keuls test

\section{Figure 6}

Effects of oral administration of EESM on edema induced by CFA. The animals received EESM (30, or 100 , p.o., daily, once a day), vehicle (control) or dexamethasone (DEXA, $1 \mathrm{mg} / \mathrm{kg}$, s.c., daily, once a day) for 6 (A), 11(B), 16 (C), and 22 (D) days. The CFA injection was performed on the first day. Each bar represents the mean \pm SEM of 6 animals. The letters $a, b$, and $c$ indicate significant differences among groups according to One-way ANOVA followed by the Newman-Keuls test

\section{Figure 7}

Effects of oral administration of EESM on cold hyperalgesia induced by CFA. The animals received EESM (30, or 100, p.o., daily, once a day), vehicle (control) or dexamethasone (DEXA, $1 \mathrm{mg} / \mathrm{kg}$, s.c., daily, once a day) for 6 (A), 11(B), 16 (C), and 22 (D) days. The CFA injection was performed on the first day. Each bar represents the mean \pm SEM of 6 animals. The letters $a$ and $b$ indicate significant differences among groups according to One-way ANOVA followed by the Newman-Keuls test

\section{Supplementary Files}

This is a list of supplementary files associated with this preprint. Click to download.

- GraphicalAbstract.png 